\title{
The Correlations Between Mercury Speciation and Dissolved Organic Matter in the Sediment of the Red Sea
}

\author{
${ }^{1}$ Wedyan, M.A., ${ }^{2}$ F.A. Ababneh and ${ }^{3}$ S. Al-Rousan \\ ${ }^{1}$ Department of Biology, Faculty of Sciences \\ ${ }^{2}$ Department of Chemistry, Faculty of Sciences \\ Al Hussein Bin Talal University, Ma'an, P.O. Box 20, Jordan \\ ${ }^{3}$ Marine Science Station, University of Jordan, P. O. Box 195, 77110 Aqaba, Jordan
}

Received 2012-03-05; Revised 2012-03-26; Accepted 2012-06-21

\begin{abstract}
This study addresses the correlations between $\mathrm{Hg}$ and organic matter in recent sediment; samples were collected from the Gulf of Aqaba, Red Sea coasts (oligotrophic regions) during 2010. In the present study TOC analyzer was used to determine Total Organic Carbon (TOC) and Total Nitrogen (TN) concentrations and the total amount of mercury $\left(\mathrm{Hg}_{\mathrm{T}}\right)$ in sediment samples were analyzed by Hydra-C mercury analyzer. The obtained results indicated that, mercury, TOC and TN average concentrations in the Red Sea were $85.42 \mathrm{ng} \mathrm{g}^{-1}, 5.10$ and $4.45 \mathrm{mg} \mathrm{L}^{-1}$, respectively. The results show that the Total Organic Carbon (TOC) in sediment represents the sum of various organic compounds, which may play a completely different role in the distribution and accumulation of $\mathrm{Hg}$. slightly correlations between the TOC and the concentration of $\mathrm{Hg}$ in the studied sediment arise mainly from the labile portion of organic matter released. These compounds primarily consist of easily degradable algal-derived lipids and various pigments, which are petrographically described as a soluble Organic Matter (OM). The preserved OM in sediment is commonly entrapped within the cell walls of phytoplankton and also appears as a surface coating on sediment particles. The strong affinity between $\mathrm{Hg}$ and $\mathrm{OM}$ is due not only to its chemical reactivity, but also to the physical characteristic of these labile compounds, which plays the most important role in the distribution of $\mathrm{Hg}$ in sediment.
\end{abstract}

Keywords: Total organic carbon, total nitrogen, mercury, sediment, gulf of Aqaba-Jordan

\section{INTRODUCTION}

Anthropogenic mercury in the aquatic environment has been an increased awareness due to their toxicity for the life so it is important to understand the fate and reactivity with such environment. Paraquetti et al. (2004) showed that the trace metal are reacted and sorbed to the suspended particulate matter. In an aquatic environment mercury occurs in different forms including elemental mercury, Ionic mercury and methyl mercury (Berthon, 1995). Methyl mercury is one of the most toxic forms of mercury species; it tends to bioaccumulate and biomagnify in the fatty tissue of fish more than other forms. Watras and Huckabee, (1994) prove that the most mercury in the most fish species occurs as methyl mercury which is transferred to human via the food chain. Mercury like other metals speciation is affected by reaction with organic and inorganic compounds that present in water.

Dissolved Organic Matter (DOM), which is ubiquitous in aquatic environments, is bind to trace metals which affect their speciation, solubility, mobility and toxicity (Buffle et al., 1988). There is increasing evidence that DOM interacts with mercury as well which is altering its speciation and bioavailability in aquatic environments (Loux, 1998). In coastal waters, more than $60 \%$ of the dissolved mercury is associated with organic matters or suspended particles (Fitzgerald and Lyons, 1973). Whereas Dissolved Organic Carbon (DOC) appears to be the most important species which control the bioavailability of mercury due to high binding capacity (Barkay et al., 1997, Cai et al., 1999). The 
previous studies showed a strong interactions between $\mathrm{Hg}$ and DOM have also been indicated by a positive correlation between their concentrations in many natural waters (Andren and Harriss, 1975; Lindberg and Harriss, 1974; Mierle and Ingram, 1991; Meili et al., 1991; Driscoll et al., 1995; Hurley et al., 1995; Watras et al., 1995; Baeyens et al., 1996; Kolka et al., 1999; Shanley et al., 2002).

Strong ionic binding is one of the most important reactions between mercury and reduced sulfur sites in soil and DOM which facilitates the mobility of mercury across water column and sediment (Wallschlager et al., 1996) and enhanced results in increased water column's mercury concentrations and help in increased sequestration of mercury in sediments (Cossa and Gobeil, 2000). The pore water's mercury that adsorbed to sediment particles may affect the biota. Generally, the highest mercury concentrations in sediments (maximum $35 \mathrm{mg} \mathrm{\textrm {g } ^ { - 1 }}$ ) were found at $30-40 \mathrm{~cm}$ depth, corresponding1 to the period of maximum industrial production (Pereira et al., 1998a). However, particulate mercury escapes when the surface sediments are resuspended and transported by the tide to the rest of the lagoon (Pereira et al., 1998b). The contribution of the dissolved mercury was not evaluated well due to the low concentrations found and reported in several studies
(Lucas et al., 1986; Pereira et al., 1998a; 1998b, Ramalhosa et al., 2001).

This study presents is the first study dealing with the distributions of reactive mercury in sediments, as well as dissolved organic matter, in Red Sea-Aqaba and contributes basic information required for regional balances of carbon and nitrogen fluxes, budgets and cycles associated with mercury.

\section{MATERIALS AND METHODS}

Study area: The study area is located at the northern end of the Gulf of Aqaba (Fig. 1), which is the northward extension of the desert-enclosed Red Sea. The maximum depth of the gulf is $1830 \mathrm{~m}$; it is $180 \mathrm{~km}$ long and 5-26 $\mathrm{km}$ wide. Oligotrophic conditions prevail in the gulf waters and evaporation $\left(350 \mathrm{~cm} \mathrm{y}^{-1}\right)$ greatly exceeds precipitation $\left(3 \mathrm{~cm} \mathrm{y}^{-1}\right)$ (Reiss and Hottinger, 1984). Surface sediment samples were collected by SCUBA divers from the upper layer of the sediment $(0-2 \mathrm{~cm})$ using cylindrical plastic tubes for the surface samples and using the cores for the core samples $(0-17 \mathrm{~cm})$, after drying; samples were sieved through 63um sieve and preserved in the freezer until analysis.

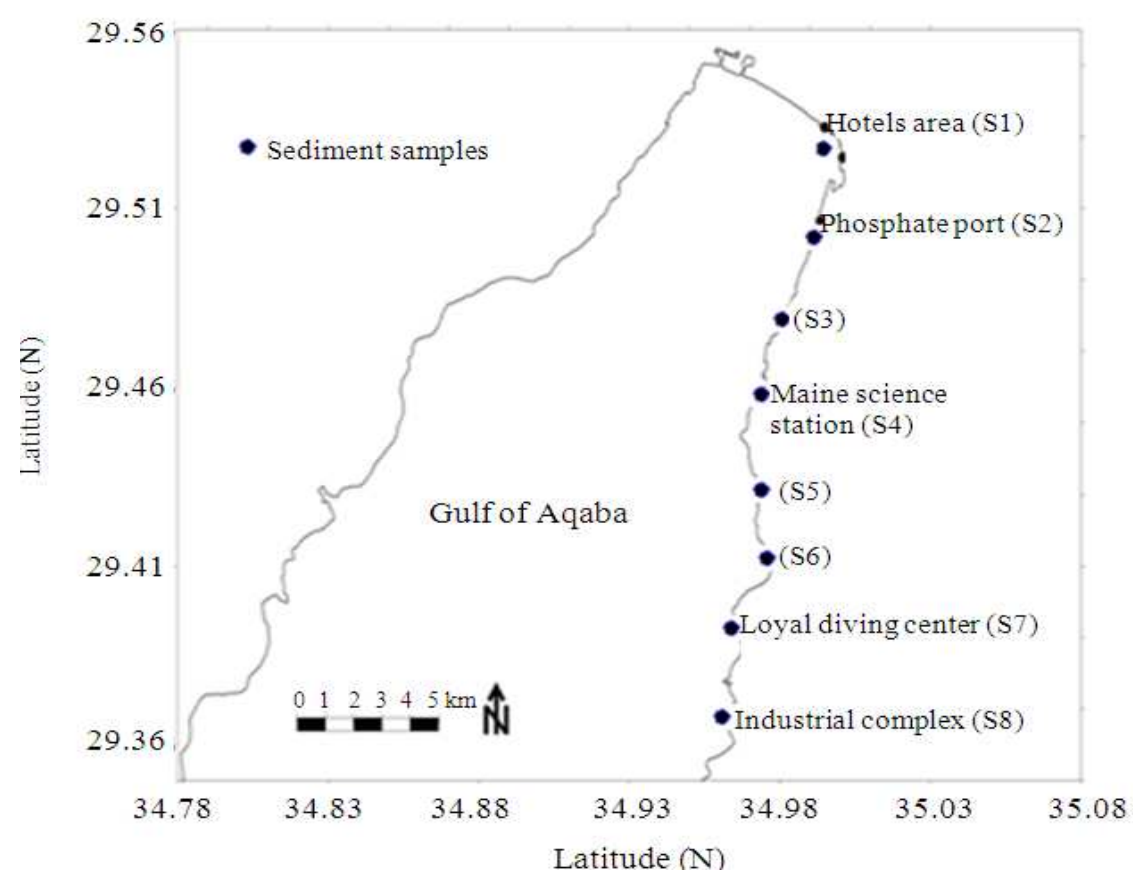

Fig. 1. Sampling site the Gulf of Aqaba ( S1; Hotel Area, S2; Phosphate Port, S3; Clink, S4; Marine Station, S5; Station 5, S6; Station6, S7; Royal Diving Center, S8, Industrial Port) 
Table 1. Correlation with the certified values

\begin{tabular}{lllllll}
\hline Sample & Certified value $\mathrm{Hg}_{\mathrm{T}}(\mu \mathrm{g} / \mathrm{g})$ measured & \% recoveries & Certified value $\mathrm{MeHg}(\mu \mathrm{g} / \mathrm{g})$ & measured Range & \% recoveries \\
\hline ERM-CC580 & 132 & 134 & 102 & 0.075 & $0.051-0.066$ & $68-88$
\end{tabular}

\subsection{Dissolved Organic Matter Extractions}

Sediment DOM was extracted by adding $10.0 \mathrm{~mL}$ of deionized $\mathrm{H}_{2} \mathrm{O}$ to $1.00 \mathrm{~g}$ of sediment 1 in a $15 \mathrm{~mL}$ centrifuge tube. The suspensions were shaken on an orbital shaker for $30 \mathrm{~min}$ at room temperature (22-18C). Centrifuged at $900 \times \mathrm{g}$ for $30 \mathrm{~min}$ and filtered through $0.45 \mathrm{~mm}$ Acrodisk syringe filters. The extraction period was selected to minimize microbial DOM alteration during extraction (Zhou and Wong, 2000).

The concentration of Total soluble Organic Carbon (TOC) in the extracts was determined using a TOC analyzer (Shimadzu's TOC-V Series/Oldenburg University, Germany). Absorbs at $240 \mathrm{~nm}$ are obtained using a diode - array detector All DOM solutions were diluted with DI-H2O to set absorbance at $240-0.10 \mathrm{~nm}$ to minimize inner filtration effects. Fluorescence measurements were obtained using a spectrofluorometer with the excitation range set from $240-400 \mathrm{~nm}$ and the emission range set from $300-500 \mathrm{~nm}$ in $3 \mathrm{~nm}$ increments. Instrumental parameters were excitation and emission slits, $5 \mathrm{~nm}$; response time, $8 \mathrm{~s}$; and scan speed, $240 \mathrm{~nm} \mathrm{~min}^{-1}$ (Zhou and Wong, 2000).

\subsection{Mercury Determination}

The total amount of mercury $\left(\mathrm{Hg}_{\mathrm{T}}\right)$ in sediment samples was determined by taking exact sample weight (200-300 mg) and the samples were analyzed by Hydra$\mathrm{C}$ mercury analyzer, this machine is capable to analyze solid and liquid samples without pre-treatments. For methyl mercury (MeHg) determination, a 0.5-1.0 g sample was extracted using $15 \mathrm{~mL}(\mathrm{HCl}: \mathrm{CH} 3 \mathrm{OH}, 1: 1$ $(\mathrm{v} / \mathrm{v})$ for $2 \mathrm{~h}$. After the extraction step, the mixture was centrifuged and the supernatant was separated from the sediment by decantation. Multi extracts were mixed and the $\mathrm{pH}$ was adjusted to 4.5 with the addition of acetate buffer, followed by derivatization with the addition of 1 $\mathrm{ml}$ of $1 \%$ sodium tetraphenylborate. The derivative, phenyl methyl mercury $(\mathrm{MeHg} \mathrm{Ph})$ was extracted with hexane and directly analyzed by GC-MS after concentration to about $1 \mathrm{~mL}$; solvent exchange to ethyl acetate also was used for the analysis by HPLCfluorescence technique.

In parallel to this procedure, a derivatization with $\mathrm{KBr}$ is now being used for other more samples. For mercury determinations, the US EPA Method 7473 was adopted; aliquots of homogenized samples were weighed $(0.1-0.3 \mathrm{~g})$ in pre-cleaned nickel boats before placement on the Hydra $\mathrm{C}$ auto sampler. Samples were analyzed based on the principle of thermal decomposition, amalgamation and atomic absorption spectrophotometry detection. The tuna fish (BCR-463) reference material was analyzed to evaluate the accuracy of the analytical method, the result $\left(\mathrm{Hg}: 2.75 \mu \mathrm{g} \mathrm{g}^{-1}\right.$ ) was in excellent agreement with the certified value ( $\mathrm{Hg}: 2.85 \mu \mathrm{g} \mathrm{g}^{-1}$ ).

Two Certified Reference Materials (CRM's) were used to evaluate the accuracy of the analytical methods; the tuna fish BCR-463 and the estuarine sediment ERMCC580. The results presented in Table 1 show excellent correlation with the certified values. Recoveries in the range of (95-102) \% and (68-80) \% was achieved for $\mathrm{Hg}_{\mathrm{T}}$ and $\mathrm{MeHg}$, respectively.

\section{RESULTS}

\subsection{Total Organic Carbon (TOC)}

The TOC values range from 7.10-2.05 $\mathrm{mg} \mathrm{L}^{-1}$ with a mean value of $5.10 \mathrm{mg} \mathrm{L}^{-1}$ and a standard deviation of 1.59 (Fig. 2) for the all sampling locations in a depth interval of $0-14 \mathrm{~cm}$. These values are not linearly related to depth. The values were relatively low in the continental slope sediments and increased within the continental rise (Fig. 3).

\subsection{Total Nitrogen (TN)}

The TN concentration ranges from 4.23-4.54 $\mathrm{mg} \mathrm{L}^{-1}$ in the superficial sediments (Fig. 2), with a mean value of 4.45 and standard deviation of 0.15 in the all stations sampled at depths from $0-17 \mathrm{~cm}$. The TN concentration in superficial sediments displays a polynomial pattern with increasing depth (Fig. 4).

\subsection{C/N Ratio}

TOC shows a direct relation with $\mathrm{TN}$ in the superficial sediments of the deep Gulf of Aqaba and adjusts to a linear regression with a correlation coefficient that explains of the cases ( $\mathrm{r} 2=0.89$; Fig. 5). The carbon-nitrogen ratio $(\mathrm{C} / \mathrm{N})$ for the samples, from depths of $0-15 \mathrm{~cm}$, has a mean value of 1.14 with a standard deviation of 0.34 . $\mathrm{C} / \mathrm{N}$ does slightly change with increasing depth. The lowest $\mathrm{C} / \mathrm{N}$ ratios are observed $(\mathrm{C} / \mathrm{N}=0.48)$ and the highest $(\mathrm{C} / \mathrm{N}=1.57)$. 


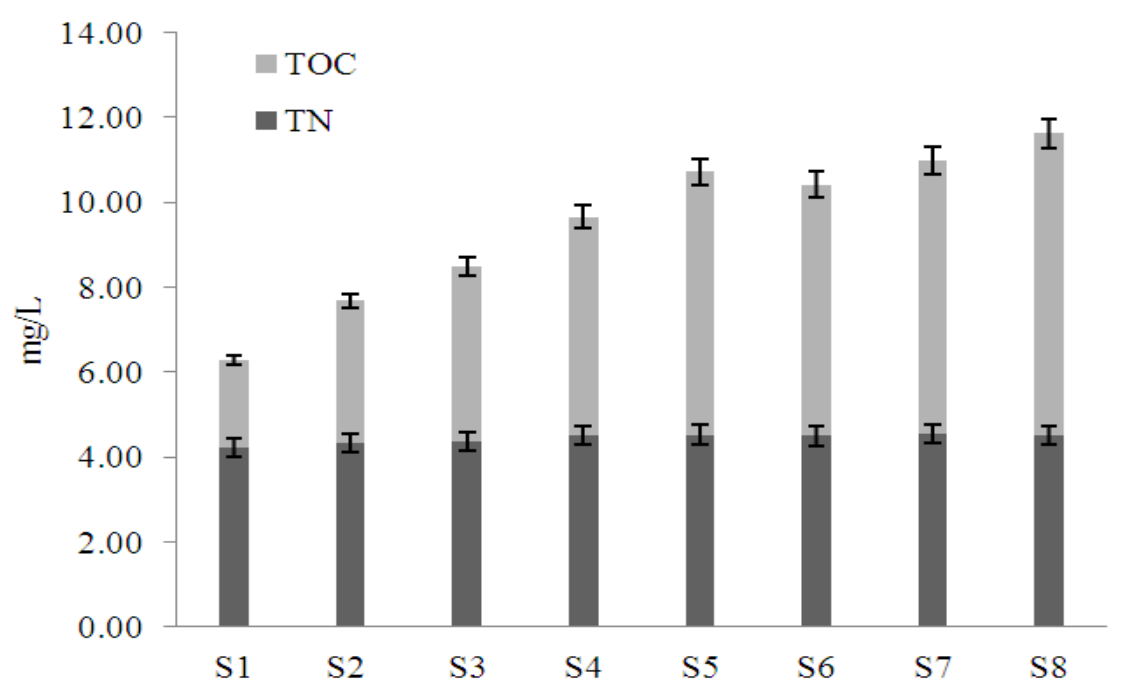

Fig. 2. The total concentrations (mg/L) of Total Organic Carbon (TOC) and Total Nitrogen (TN)

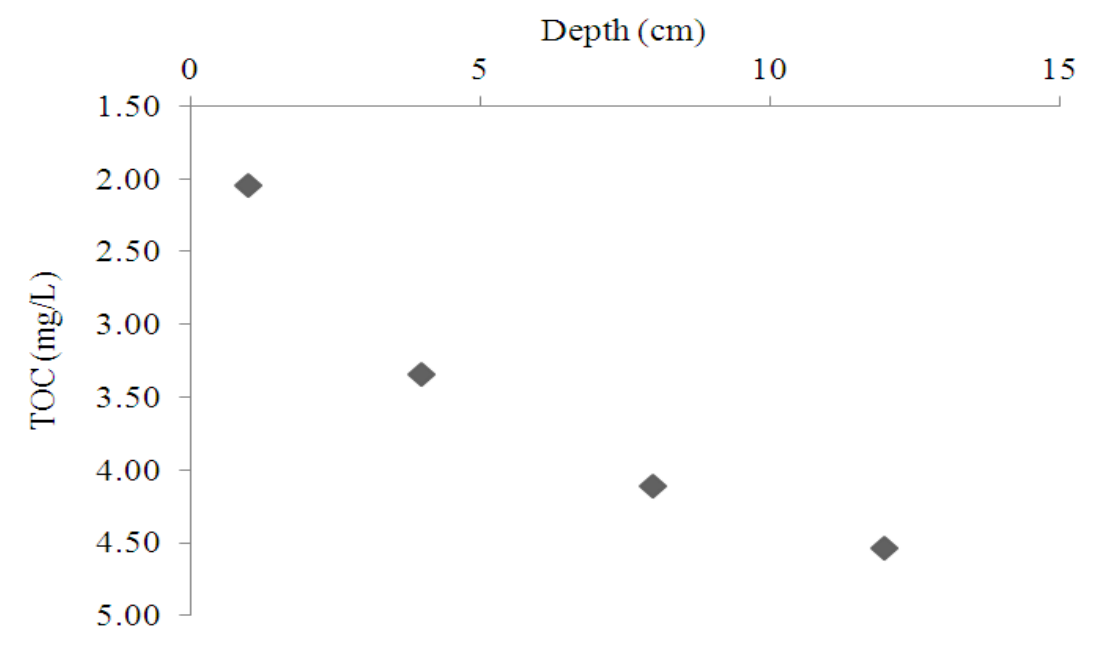

Fig. 3. The total concentrations $(\mathrm{mg} / \mathrm{L})$ of TOC with depth $(\mathrm{cm})$

\subsection{Total Mercury}

As shown in Fig. 6, the concentration of total mercury (all forms of mercury, including inorganic and methylmercury) in the top centimeters of Gulf of Aqaba sediments ranges from approximately 28.9-176.60 ng of mercury per gram of dry sediment and ( StD 4.25, 18.0 respectively). While sediment mercury concentration generally correlated with organic matter content, the sharp peak in sediment mercury we observed in the top centimeters does correspond to a high organic matter content. It is instead due to the point source of mercury.
Comparisons between variations of organic matter throughout the sediment cores and the concentrations of $\mathrm{Hg}$ were carried out using a leaner regression correlation. The correlation coefficients between the TOC, TN and the concentrations of $\mathrm{Hg}$ in the core are shows a significant value (Fig. 7a and b). The relationship between $\mathrm{Hg}$ and organic compounds throughout the Aqaba sediment core is also shown as a regression plot reiterating a poor relationship between $\mathrm{Hg}$, TOC. However, the linear relationship between $\mathrm{Hg}$ and $\mathrm{TN}$ indicates that the distribution of $\mathrm{Hg}$ in the Aqaba sediment samples mainly relates to the labile compounds. 
Wedyan, M.A. et al. / American Journal of Environmental Science 8(4) (2012) 403-411

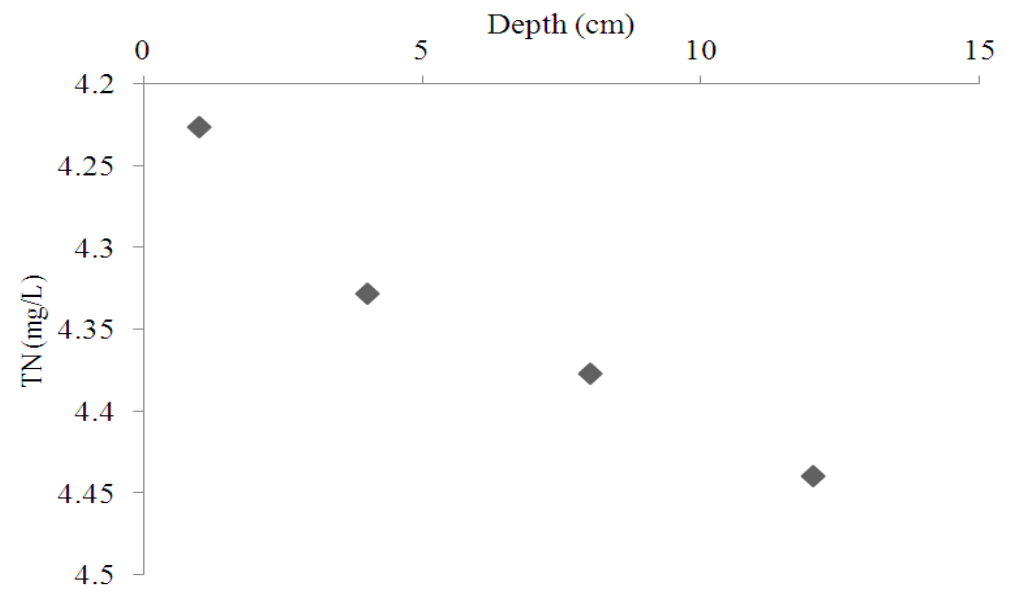

Fig. 4. The total concentrations $(\mathrm{mg} / \mathrm{L})$ of $\mathrm{TN}$ with depth $(\mathrm{cm})$

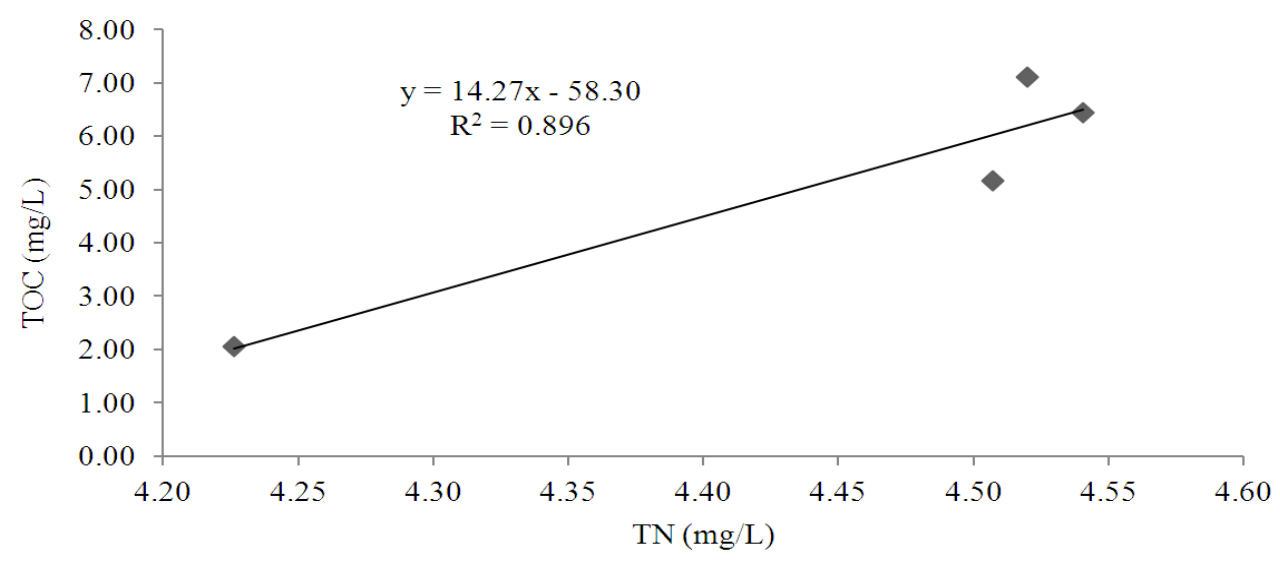

Fig. 5. Relationships between TOC and TN

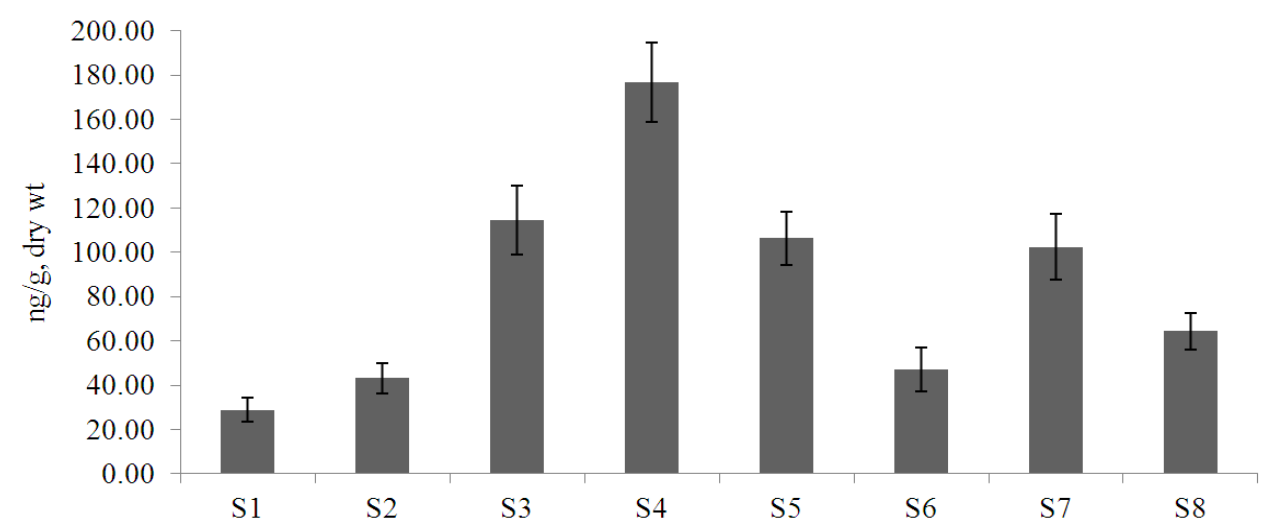

Fig. 6. The concentration of total mercury (all forms of mercury, including inorganic and methylmercury (in the top centimeters of Gulf of Aqaba sediments 


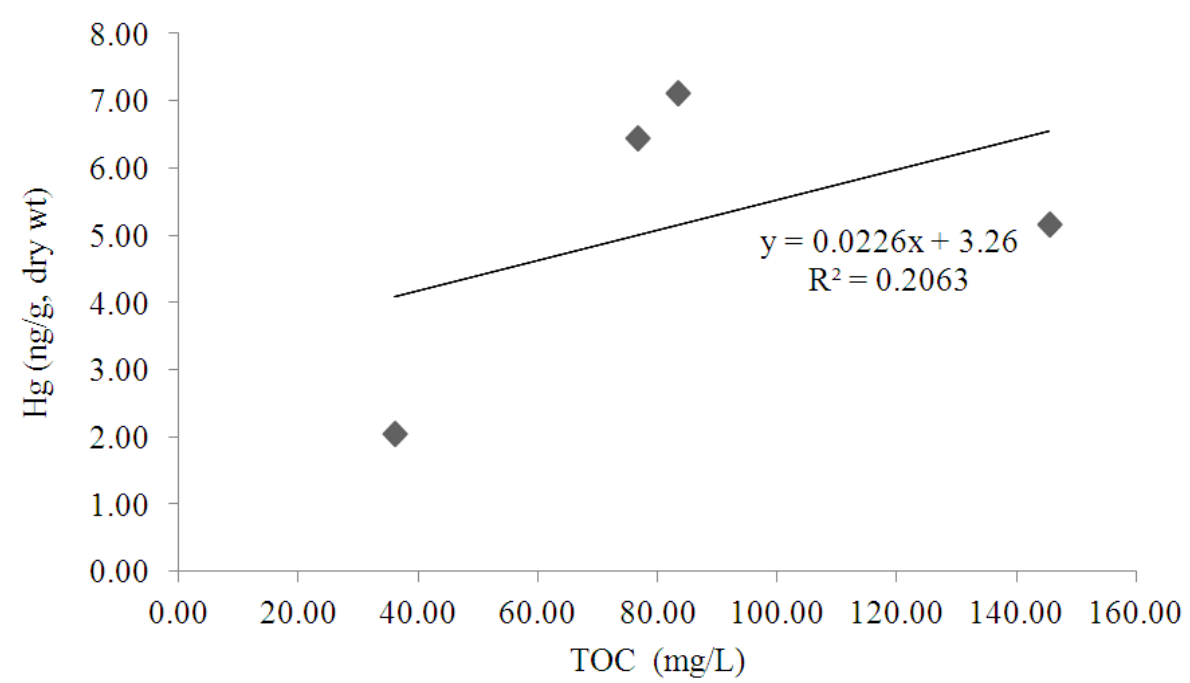

(a)

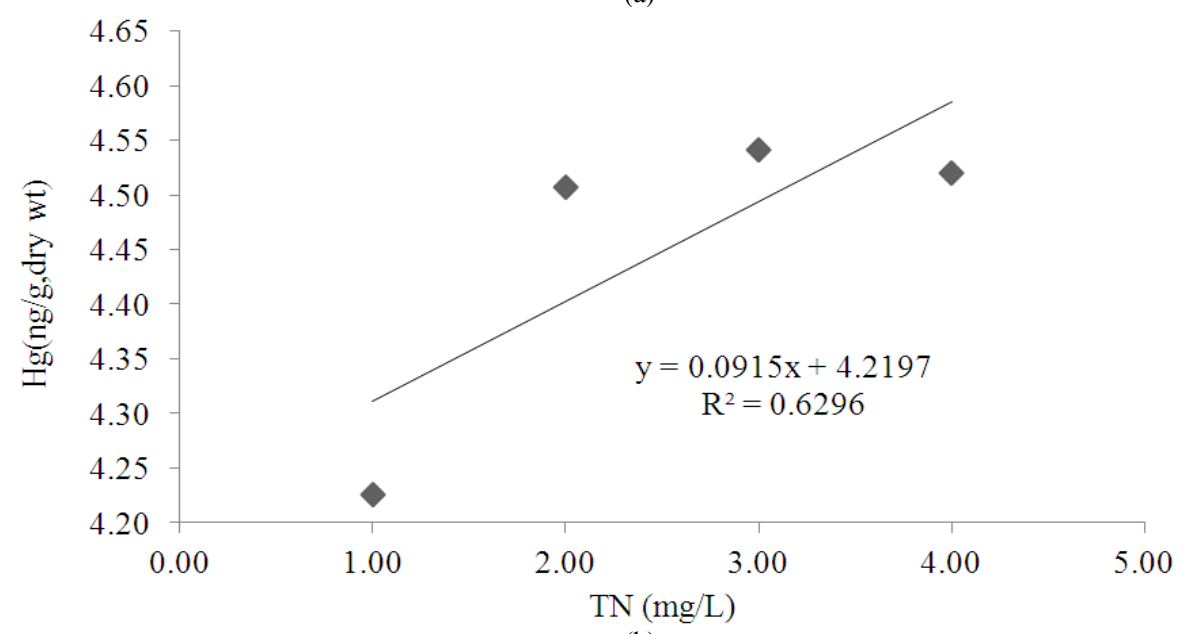

(b)

Fig. 7. (a and b) Relationship between $\mathrm{Hg}$ and organic matter

\section{DICUSSION}

Seiter et al. (2004) demonstrated TOC values for sediments under well oxygenated conditions are $<0.5 \%$. The mean values recorded in this study are slightly higher than expected $(1.02 \pm 0.3 \%$, range $0.41-1.42 \%$, but lower than those recorded in the continental margins ( $>1.5 \%$ in Seiter et al., 2004; $4-16 \%$ in Arthur et al., 1998). The TOC values are similar to those recorded in the northern Gulf of Mexico (0.34-1.59\% in Goni et al., 1997; 1998; Gordon and Goni, 2004; 0.37-1.3\% in Morse and Beazley, 2008) and those from other basins at similar latitudes, i.e.,: The Argentina Basin $(0.26-1.72 \%$ in Stevenson and Cheng, 1972) and the Arabian Sea (0.04-
$1.5 \%$ in Grandel et al., 2000). The highest value of this study is in agreement with the values described by Seiter et al. (2004) for tropical regions, including the continental margin of western Africa.

The $\mathrm{TN}$ values span over a narrow range $(\mathrm{TN}=$ $0.85-0.91 \%$ ) which are higher than those expected for the northern sector of the Gulf of Mexico ( $\mathrm{TN}=0.08-0.17 \%$ in Goni et al., 1998; Gordon and Goni, 2004). This is explained by the broadest geographical coverage of this study. The obtained TN values are higher for those from the Argentina Basin (TN $=0.031-0.167 \%$ in Stevenson and Cheng, 1972) and than those recorded in the continental margin of the Arabian Sea $(0.1-0.4 \%$ in Suthhof et al., 2000) and than those recorded in the China Sea (0.02-0.19\% in Kao et al., 2003). 
The organic material of photoautotrophic origin mixes with continental organic matter near the coast and is usually transported by turbidity currents to the abyssal plain (Suthhof et al., 2000; Mari et al., 2001; Epping et al., 2002; Gordon and Goni, 2004). Values of CarbonNitrogen atomic ratio $(\mathrm{C} / \mathrm{N})$ suggests an organic matter input derived from vascular plants (Meyers, 1994), characterized by limiting nitrate concentration (Mari et $a l ., 2001)$. The mean value of our study $(\mathrm{C} / \mathrm{N}=1.41 \pm$ $0.34)$ is lower the Redfield ratio $(\mathrm{C} / \mathrm{N}=5.7$; Gordon and Goni, 2004; Weston and Joye, 2005). The TN of the sediments avoids being remineralized into the water column by adsorption to the mineral clay surface, hence recording smaller $\mathrm{C} / \mathrm{N}$ ratios (Stevenson and Cheng, 1972; Suthhof et al., 2000) that are explained by selective degradation of the organic compounds and by immobilization of $\mathrm{N}$ by microorganisms during early diagenesis (Meyers, 1994). Other factors that can indicate the origin of organic matter in the sediments, but not performed in this study, include the Hydrogen index, microscopic observations and carbon stable isotopic composition (Stein, 1990; 1991). The stable isotope composition of particulate organic matter in deep seawater samples from the same stations in the Gulf of Mexico $(\delta 13 \mathrm{C}-25.3$ to $-22.70 \%$ in the abyssal plain and $\delta 13 \mathrm{C}-24.11$ to $-22.12 \%$ in the continental slope) indicate a photoautotrophic origin, with depleted values caused by the time of residence in the water column with a contribution of suspended material from the sediment (González-Ocampo, 2005; González-Ocampo et al., 2007).

The surface sediments collected in this study presented mercury concentrations comparable to the values recorded in a previous study (Pereira et al., 1998a). In the present study, the highest mercury contents were found in the area near the industrial discharge and were positively correlated to both the organic carbon and total nitrogen. The organic carbon present sediments may result from industrial effluents and also from the decomposition of extensive algae coverage and plankton inside the gulf, as stated by Monterroso et al. (2003).

The previous studies of Schuster et al. (2008) and Selvendiran et al. (2008a) showed that there is a connection of wetlands and riparian areas to streams during hydrologic events can flush stored organic matter and $\mathrm{Hg}$ to downstream ecosystems. Both dissolved and particulate $\mathrm{C}$ plays an essential role in the transport of $\mathrm{Hg}$ fractions. The result of the this study is in agreement with other studies in the region that report DOC as an important transport mechanism for THg (Driscoll et al., 1995; Selvendiran et al., 2008b; Shanley et al., 2008).
There was a consistent relationship between $\mathrm{Hg}$ and DOC across our sites with, which is higher than the studied reported by Grigal (2002) for sites across the Northern Hemisphere. The similar slopes between our study and those reported by Grigal (2002) for the THg DOC relationship are likely a function of strong correlation between FTHg and the export of humic material associated with hydrophobic organic matter (Mierle and Ingram, 1991; Grigal, 2002).

\section{CONCLUSION}

Sediments can be a source of dissolved mercury and organic matter because of the activity of microorganisms. As the deposited mercury is buried beneath new layers of sediment, organic matter in the sediment is consumed by certain types, by bacteria living a few millimeters below the sediment water interface, beyond the reach of oxygen. These bacteria get their energy through chemical reactions that involve sulfur and iron and produce toxic methylmercury as a byproduct.

\section{ACKNOWLEGMENT}

The researchers wish to thank The Jordan Scientific Research Fund (SRSF) for the financial support (No. S1/04/2008).

\section{REFERACES}

Andren, A.W. and R.C. Harriss, 1975. Observations of the association between mercury and organic matter dissolved in natural waters. Geochim. Cosmochim. Acta, 39: 1253-1257. DOI: 10.1016/0016-7037 (75)90132-5

Arthur, M.A., W.E. Dean and K. Laarkamp, 1998. Organic carbon accumulation preservation in surface sediments on the Peru margin. Chemical Geol., 152: 273-286. DOI: 10.1016/S0009-2541 (98)00120-X

Barkay, T., M. Gillman, R.R. Turner, 1997. Effects of dissolved organic carbon and salinity on bioavailability of mercury. Appl. Environ. Microbiol. 63: 4267-4271.

Buffle, J., R.A. Chalmers, M.R. Masson and D. Midgley, 1988. Complexation Reactions in Aquatic Systems: An Analytical Approach. 1st Edn., Halsted Press, Chichester, ISBN-10: 0853125570 pp: 692.

Cai, Y., R. Jaffe and R.D. Jones, 1999. Interactions between dissolved organic mercury species in surface waters of the Florida Everglades. Appl. Geochem., 14: 395-407. DOI: 10.1016/S08832927(98)00053-5 
Cossa, D. and C. Gobeil, 2000. Mercury speciation in the lower St. Lawrence Estuary. Can. J. Fish. Aquat. Sci., 57: 138-147.

Driscoll, C.T., V. Blette, C. Yan, C.L. Schofield and R. Munson et al., 1995. The role of dissolved organic carbon in the chemistry and bioavailability of mercury in remote Adirondack lakes. Water, Air, Soil Pollut., 80: 499-508. DOI: 10.1007/BF01189700

Epping, E., C. Van Der Zee, K. Soetaert and W. Helder, 2002. On the oxidation and burial of organic carbon in sediments of the Iberian margin and Nazaré Canyon (NE Atlantic). Progress Oceanography, 52: 399-431. DOI: 10.1016/S0079-6611 (02)00017-4

Fitzgerald, W.B. and S. Lyon, 1973. Organic mercury compounds in coastal waters. Nature, 242: 452-453. PMID: 4700898

Goni, M.A., K.C. Ruttenberg and T.I. Eglinton, 1998. A reassessment of the sources and the importance of land-derived organic matter in surface sediments from the Gulf of Mexico. Geochimica et Cosmochimica Acta, 62: 3055-3075. DOI:

Goni, M.A., K.C. Ruttenberg and T.I. Eglinton, 1997. Sources and contribution of terrigenous organic carbon to surface sediments in the Gulf of Mexico. Nature, 389: 275-278. DOI: 10.1038/38477

González-Ocampo, M., 2005, Composicin y Caracterizacin Isotpica $\delta 13 \mathrm{C}$ de PartيCulas de Carbono Org JNico en Estratos Batimétricos de Aguas OceJNicas del Suroeste del Golfo de México. 1st Edn., Universidad Nacional Autnoma de México, México, pp: 76.

González-Ocampo, M., E. Escobar-Briones and P. Morales, 2007. Composición y Caracterización Isotópica $\delta 13 \mathrm{C}$ de Carbono Orgánico Particulado Enaguas Oceánicas Del Sureste Del Golfo de México. In: Gaxiola Castro, Hernández, G.B. (Ed.). Carbono en Ecosistemas Acuáticos de México: INECicese, México, pp: 75-100.

Gordon, E.S. and M.A. Goni, 2004. Controls on the distribution and accumulation of terrigenous organic matter in sediments from the Mississippi and Atchafalaya river margin. Marine Chemistry, 92: 331-352. DOI: 10.1016/j.marchem.2004.06.035

Grandel, S., D. Rickert, M. Schlüter and K. Wallmann, 2000. Pore-water distribution and quantification of diffusive benthic fluxes of silicic acid, nitrate and phosphate in surface sediments of the deep Arabian Sea: Deep-Sea Res., 47: 2707-2734. DOI: 10.1016/S0967-0645(00)00046-1
Grigal, D.F., 2002. Inputs and outputs of mercury from terrestrial watersheds: A review. Environ. Rev., 10: 1-39.

Berthon, G., 1995. Handbook of Metal-Ligand Interactions in Biological Fluids: Bioinorganic Medicine. 1st Edn., Dekker, New York, ISBN-10: $0824796373 \mathrm{pp}: 1523$.

Hurley, J.P., J.M. Benoit, C.L. Babiarz, M.M. Shafer and A.W. Andren et al., 1995. Influences of watershed characteristics on mercury levels in Wisconsin rivers. Environ. Sci. Technol., 29: 1867-1875. PMID: 22176462

Kao, S.J., F.J. Lin and K.K. Liu, 2003. Organic carbon nitrogen contents their isotopic compositions in surficial sediments from the East China Sea shelf the southern Okinawa Trough . Deep-Sea Research II, 50: 1203-1217. DOI: 10.1016/S0967-0645 (03)00018-3

Kolka, R.K., D.F. Grigal, E.S. Verry and E.A. Nater, 1999. Mercury and organic carbon relationships in streams draining forested upland/peatland watersheds. J. Environ. Q., 28: 766-775.

Lindberg, S.E. and R.C. Harriss, 1974. Mercury-organic matter associations in estuarine sediments and interstitial water. Environ. Sci. Technol., 8: 459-462. DOI: $10.1021 /$ es60090a009

Loux, N.T., 1998. An assessment of mercury-speciesdependent binding with natural organic carbon. Chem. Spec. Bioavail., 10: 127-136. DOI: 10.3184/095422998782775754

Lucas, M.F., M.T. Caldeira, A. Hall, A.C. Duarte and C. Lima, 1986. Distribution of mercury in the sediments and fishes of the lagoon of Aveiro, Portugal. Water Sci. Technol., 18: 141-148.

Mari, X., S. Beauvais, R. Lemée and M.L. Pedroti, 2001. Non-Redfield $\mathrm{C}$ : $\mathrm{N}$ ratio of transparent exopolymeric particles in the northwestern Mediterranean Sea. Limnology Oceanography, 46: 1831-1836.

Meili, M., A. Iverfeldt and L. Hakanson, 1991. Mercury in the surface water of Swedish forest lakes concentrations, speciation and controlling factors. Water Air Soil Pollut., 56: 439-453. DOI: 10.1007/BF00342290

Meyers, P.A., 1994. Preservation of elemental and isotopic source identification of sedimentary organic matter. Chemical Geol., 114: 289-302. DOI: 10.1016/0009-2541 (94)90059-0

Mierle, G. and R. Ingram, 1991. The role of humic substances in the mobilization of mercury from watersheds. Water, Air, Soil Pollut., 56: 349-357. DOI: $10.1007 / \mathrm{BF} 00342282$ 
Monterroso, P., S.N. Abreu, E. Pereira, C. Vale and A.C. Duarte, 2003. Estimation of $\mathrm{Cu}, \mathrm{Cd}$ and $\mathrm{Hg}$ transported by plankton from a contaminated area (Ria de Aveiro). Acta Oecologica, 24: S351-S357. DOI: 10.1016/S1146-609X(03)00033-X

Morse, J.W. and M.J. Beazley, 2008. Organic matter in deepwater sediments of the Northern Gulf of Mexico its relationship to the distribution of benthic organisms. Deep-Sea Res., 55: 2563-2571. DOI: 10.1016/j.dsr2.2008.07.004

Paraquetti, H.H., G.A. Ayres, M.D.A. Almeida, M.M. Molisani and L.D. de Lacerda, 2004. Mercury distribution, speciation and flux in the Sepetiba Bay tributaries, SE Brazil. Water Res., 38: 1439-1448. PMID: 15016520

Pereira, M.E., A.C. Duarte, G.E. Millward, S.N. Abreu and C. Vale, 1998a. An estimation of industrial mercury stored in sediments in a confined area of the lagoon of Aveiro Portugal. Water Sci. Technol., 37: 125-130. DOI: 10.1016/S0273-1223 (98)00191-7

Pereira, M.E., A.C. Duarte, G.E. Millward, C. Vale and S.N. Abreu, 1998b. Tidal export of particulate mercury from the most contaminated area of Aveiro's Lagoon, Portugal. Portugal. Sci. Total Environ., 213: 157-163. DOI: 10.1016/S00489697(98)00087-4

Watras, C.J. and J.W. Huckabee, 1994. Mercury Pollution: Integration and Synthesis. 1st Edn., Lewis Press, Boca Raton, ISBN-10: 1566700663 pp: 727.

Ramalhosa, E., P. Monterroso, S. Abreu, E. Pereira and C. Vale et al., 2001. Storage and export of mercury from a contaminated bay (Ria de Aveiro, Portugal). Wetlands Ecol. Manage., 9: 311-316.

Reiss, Z. and L. Hottinger, 1984. The Gulf of Aqaba, ecological micropaleontology Ecol. Stud., 50: 1-354.

Schuster, P.F., J.B. Shanley, M. Marvin-Dipasquale, M.M. Reddy and G.R. Aiken et al., 2008. Mercury and organic carbon dynamics during runoff episodes from a northeastern USA watershed. Water Air Soil Pollut, 187: 89-108. DOI 10.1007/s11270-007-9500-3

Seiter, K., C. Hensen, J. Schrter and M. Zabel, 2004. Organic carbon in surface sediments-defining regional provinces. Deep Sea Res., 51: 2001-2026. DOI: $10.1016 /$ j.dsr.2004.06.014

Selvendiran, P., C.T. Driscoll, J.T. Bushey and M.R. Montesdeoca 2008a. etlands influence on mercury fate transport in a temperate forested watershed. Environ. Pollut., 154: 46-55. DOI: $10.1016 / \mathrm{j}$. envpol. 2007.12.005
Selvendiran, P., C.T. Driscoll, M.R. Montesdeoca and J.T. Bushey 2008b. Inputs, storage and transport of total and methyl mercury in two temperate forests wetlands. J. Geophys. Res., 113: G00C01- G00C01. DOI: 10.1029/2008JG000739

Shanley, J.B., M.M. Alisa, D.H. Campbell, G.R. Aiken, D.P. Krabbenhoft et al., 2008, Comparison of total mercury and methylmercury cycling at five sites using the small watershed approach, Environ. Pollut., 154: 143-154. PMID: 18407389

Shanley, J.B., P.F. Schuster, M.M. Reddy, D.A. Roth and H.E. Taylor et al., 2002. Mercury on the move during snowmelt in Vermont. EOS, 83: 45-48. DOI: 10.1029/2002EO000031

Stein, R., 1990. Organic carbon content/sedimentation rate relationship and its paleoenvironmental significance for marine sediments. Geo-Marine Lett., 10: 37-44. DOI: 10.1007/BF02431020

Stein, R., 1991. Accumulation of Organic Carbon in Marine Sediments. 1st Edn., Springer-Verlag, Berlin, ISBN-10: 3540538135 pp: 217.

Stevenson, F.J. and C.N. Cheng, 1972. Organic geochemistry of the Argentine basin sediments: carbon-nitrogen relationships and quaternary correlations. Geochimica et Cosmochimica Acta, 36: 653-671. DOI: 10.1016/0016-7037 (72)90109-3

Suthhof, A., T.C. Jennerjahn, P. Schufer and V. Ittekkot, 2000. Nature of organic matter in surface sediments from the Pakistan continental margin and the deep Arabian Sea: Amino acids. Deep Sea Res., 47: 329351. DOI: 10.1016/S0967-0645 (99)00109-5

Baeyens, W.R.G., R. Ebinghaus, O.F. Vasilev and O. Vasiliev, 1996. Global and Regional Mercury Cycles: Sources Fluxes and Mass Balances. 1st Edn., Kluwer Academic Publishers, Dordrecht, ISBN-10: 079234314X pp: 563.

Wallschlager, D., M.V.M. Desai and R.D. Wilken, 1996. The role of humic substances in the aqueous mobilization of mercury from contaminated floodplain soils. Water, Air, Soil Pollut., 90: 507-520. DOI: 10.1007/BF00282665

Watras, C.J., K.A. Morrison and N.S. Bloom, 1995. Chemical correlates of hg and methyl-hg in northern wisconsin lake waters under ice-cover. Water, Air, Soil Pollut., 84: 253-267. DOI: 10.1007/BF00475343

Weston, N.B. and S.B. Joye, 2005. Temperature-driven decoupling of key phases of organic matter degradation in marine sediments. PNAS, 102: 17036-17040. DOI: 10.1073/pnas.0508798102

Zhou, L.X. and J.W.C. Wong, 2000. Microbial decomposition of dissolved organic matter and its control during a sorption experiment. J. Environ. Quality, 29: 1852-1856. 
Wedyan, M.A. et al. / American Journal of Environmental Science 8(4) (2012) 403-411 